\title{
FAKTOR PENDORONG DAN PENGHAMBAT PEMBANGUNAN WISATA EDUKASI PERTANIAN DI BALAI BENIH HORTIKULTURA KABUPATEN GARUT
}

\author{
SUPPORTING AND OBSTACLE FACTORS OF AGRO-EDUTOURISM \\ DEVELOPMENT IN HORTICULTURAL SEED CENTER, GARUT DISTRICT
}

\author{
Syifa Al Mani*, Lucyana Trimo \\ Fakultas Pertanian, Universitas Padjadjaran \\ * E-mail: syifaalmani30@gmail.com \\ (Diterima 24-1-2021; Disetujui 29-1-2021)
}

\begin{abstract}
ABSTRAK
Wisata agro merupakan bentuk dari perkembangan sektor wisata yang berubah sesuai zaman. Pemanfaatan lahan dan kegiatan pertanian adalah salah satu media untuk pembangunan sektor pertanian yang umumnya mengandalkan kegiatan budidaya. Melihat potensi Kabupaten Garut sebagai daerah yang kaya akan destinasi wisata dengan berbagai keunikan yang dimiliki, Balai Benih Hortikultura sebagai Unit Pelaksana Teknis Daerah di bawah Dinas Pertanian berencana untuk melakukan optimalisasi fungsi lembaga melalui pembangunan wisata edukasi pertanian. Namun dalam pelaksanaan berbagai kegiatan operasional sehari-hari, lembaga tersebut dihadapi oleh permasalahan anggaran, keterbatasan sumber daya manusia dari segi jumlah dan kompetensi, serta keberadaan sarana dan prasarana yang kurang memadai. Hal tersebut dapat mempengaruhi produktivitas lembaga dan menghambat realisasi proyek. Penelitian ini bertujuan untuk mengidentifikasi berbagai faktor pendorong dan penghambat yang mempengaruhi pembangunan wisata edukasi pertanian di BBH. Penelitian dilakukan menggunakan metode kualitatif dengan teknik studi kasus untuk eksplorasi berbagai data sesuai dengan kondisi dan keunikan objek. Data penelitian diperoleh melalui observasi, wawancara mendalam, dokumentasi, dan studi literatur, yang selanjutnya akan dianalisis menggunakan matriks IFAS dan EFAS, yang nantinya dapat dijadikan pertimbangan dalam proyek pembangunan yang dilakukan. Faktor pendorong dalam menjalankan pembangunan adalah kondisi berbagai sumber daya yang mendukung, proyek yang berorientasi pada aspek pendidikan, belum adanya pesaing, adanya komitmen dan dukungan dari berbagai pemangku kepentingan, serta sektor pertanian yang masih menjadi andalan perekonomian. Faktor penghambat pembangunan meliputi perencanaan yang kurang sesuai dengan tupoksi, keterbatasan sumber daya, tingginya kebergantungan pada pemerintah, keberlanjutan proyek yang terhambat jika ada pergantian pimpinan, kurangnya sosialisasi kepada masyarakat, serta adanya pandemik COVID-19.
\end{abstract}

Kata Kunci : Pembangunan, Wisata Edukasi, Pertanian, Balai Benih Hortikultura

\section{ABSTRACT}

Agro tourism is tourism sector development form which changes by the times. Cultivation activities coupled with agricultural land and activities can be used as the way to develop related sector. Horticultural seed center (BBH) as a regional technical unit under Department of Agriculture has a plan to optimize the institution's role and function through the agricultural edutourism project by seeing the potential and uniqueness of tourist-destination of Garut Regency. The institution's operational activities faced with budget problem, limited human resoureces in terms of number and competencies, also the existence of inadequate facilities and infrastucture. Those things can affect the productivity and hinder project realization. This study aims to identify supporting and obstacle factors that influence to agro-edutourism project in BBH. The research using a qualitative methods and case study techniques to expolate various data according to object's condition. The data were obtained from observation, in-depth interviews, documentation, and literature studies, then 


\section{FAKTOR PENDORONG DAN PENGHAMBAT PEMBANGUNAN WISATA EDUKASI PERTANIAN \\ DI BALAI BENIH HORTIKULTURA KABUPATEN GARUT \\ Syifa Al Mani, Lucyana Trimo}

analyzed by using IFAS and EFAS matrices and it can be taken into consideration for the project. The driving factors are : condition of supportive resources, the concept is oriented towards education, there are no competitors yet, commitment and support form stakeholders, and agricultural sector still dominates economic activity. The inhibiting factors are : inadequate planning with main task and function, limited resources, high dependency on government, leader's changing affects on project completion, lack of socialization by BBH to the community, also the COVID-19 pandemic.

Keywords : Development, Edutourism, Agriculture, Horticultural Seed Center

\section{PENDAHULUAN}

Pariwisata merupakan salah satu penyumbang devisa terbesar di bawah migas, batu bara, dan kelapa sawit pada tahun 2015, Kementerian Pariwisata menyebutkan pendapatan dari sektor tersebut mencapai $\mathrm{Rp} \quad 169$ triliun. Peningkatan penerimaan devisa dari sektor pariwisata berbanding lurus dengan jumlah kedatangan wisman ke berbagai destinasi wisata di Indonesia.

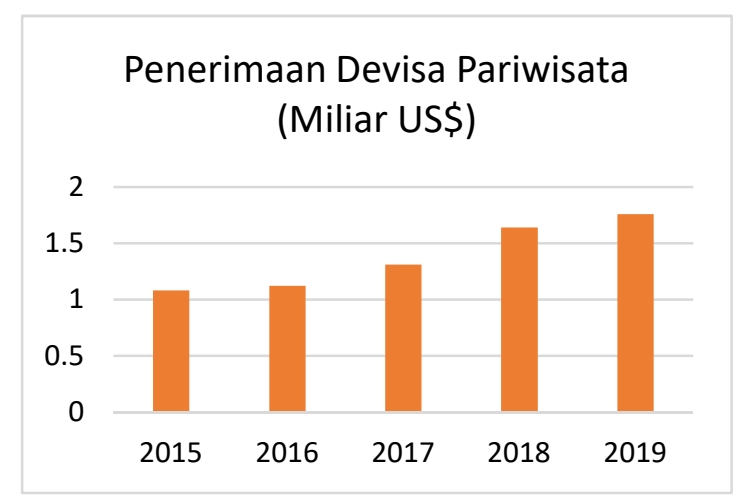

Gambar 1. Grafik Penerimaan Devisa dari Sektor Pariwisata tahun 2015-2019

Sumber : databoks.katadata.co.id

Seiring perkembangan zaman, daya tarik wisata tidak hanya berasal dari wisata bahari maupun wisata budaya, pemanfaatan lahan dan kegiatan pertanian kini dapat menjadi referensi untuk berekreasi. Wisata pertanian merupakan salah satu cara untuk mengoptimalkan pembangunan sektor pertanian yang selama ini berfokus pada kegiatan produksi. Jasa yang ditawarkan dapat berperan sebagai media promosi produk pertanian, sarana pembelajaran, serta kawasan pertumbuhan wilayah.

Destinasi wisata pertanian dapat dikelola oleh masyarakat, pihak swasta, dan pemerintah. Beberapa contoh objek wisata agro di Jawa Barat adalah Kebun Begonia, Taman Wisata Mekar Sari, Taman Bunga Nusantara, dan Perkebunan Gunung Mas PTP XII (PTPN VIII). Pengembangan wisata berbasis pertanian perlu disesuaikan dengan kapabilitas, tipologi, dan fungsi ekologis lahan. Upaya tersebut dapat berpengaruh terhadap kelestarian sumber daya lahan, pendapatan petani dan masyarakat sekitar, serta penyebarluasan teknologi dan budaya lokal (Purnama dan Agus dalam situs web Dinas Perkebunan Provinsi Jawa Barat, 2014).

Kabupaten Garut merupakan salah satu daerah di Jawa Barat yang berpotensi berkembang melalui aktivitas pertanian dengan luas wilayah administratif sekitar 
3.065,19 $\mathrm{km}^{2}$ dengan curah hujan tinggi serta lahan yang subur. Daerah tersebut dikenal dengan berbagai keunikan dan destinasi wisata yang melimpah seperti Gunung Papandayan, Taman Air Tirta Drajat, Kebun Jeruk Edukasi EPTILU, dan Air Panas Cipanas. Jumlah wisatawan yang datang pada tahun 2015-2019 cukup berfluktuatif. Kabupaten Garut biasanya dijadikan tempat singgah sementara bagi wisatawan yang bepergian dari Bandung dan Bali.

Tabel 1. Jumlah Wisatawan ke Objek Wisata Kabupaten Garut tahun 2015-2019

\begin{tabular}{cccc}
\hline Tahun & $\begin{array}{c}\text { Wisatawan } \\
\text { Mancanegara } \\
\text { (orang) }\end{array}$ & $\begin{array}{c}\text { Domestik } \\
\text { (orang) }\end{array}$ & $\begin{array}{c}\text { Total } \\
\text { (orang) }\end{array}$ \\
\hline 2015 & 4.334 & 1.874 .222 & 1.878 .556 \\
2016 & 4.938 & 671.858 & 676.841 \\
2017 & 4.934 & 1.650 .983 & 1.655 .917 \\
2018 & 3.025 & 2.676 .632 & 2.679 .657 \\
2019 & 1.275 & 2.850 .534 & 2.851 .809 \\
\hline
\end{tabular}

Sumber: Badan Pusat Statistik (2020) dan inilahkoran.com (2019)

Melihat kondisi tersebut, Balai Benih Hortikultura (BBH) sebagai salah satu Unit Pelaksanaan Teknis Daerah (UPTD) di bawah Dinas Pertanian Kabupaten Garut berusaha mengembangkan potensi wisata daerah melalui pembangunan wisata edukasi pertanian. Hal tersebut merupakan bagian dari proyek perubahan $\mathrm{BBH}$ periode jangka panjang (1-2 tahun) dalam rangka penataan fasilitas dan pengelolaan lembaga, dengan harapan mampu meningkatkan Pendapatan Asli Daerah (PAD) nonpajak. Perubahan yang dicanangkan pihak BBH melalui wisata edukasi pertanian bertujuan untuk menarik minat masyarakat khususnya anak muda, dimana tempat tersebut menyajikan fasilitas belajar dan berekreasi.

Balai Benih Hortikultura (BBH) merupakan satuan kerja di bawah dan bertanggung jawab kepada Kepala Dinas Provinsi yang membidangi hortikultura, bertugas dalam produksi dan penyebarluasan benih bermutu varietas unggul. Dalam melaksanakan tugasnya, lembaga ini menyelenggarakan fungsi produksi, penyebarluasan benih kepada masyarakat, observasi penerapan teknologi, melaksanakan pengumpulan klon/varietas tanaman yang sudah dilepas, pelaksanaan pemurnian kembali varietas unggul, pembinaan teknis, penyebarluasan informasi, serta pengawasan internal mutu benih. Hal tersebut diatur dalam Keputusan Menteri Pertanian Nomor 347/Kpts/OT.210/2003 tentang Pedoman Pengelolaan Balai Benih Tanaman dan atau Hortikultura. Struktur organisasi dari BBH terdiri atas unsur pimpinan, unsur pembantu pimpinan, unsur pelayanan teknis, dan pejabat fungsional

Terdapat persyaratan sarana dan prasarana dimana lokasi balai benih harus strategis, mempunyai lahan produksi dan kantor yang memadai, adanya ruang pertemuan, laboratorium, rumah kaca, 
rumah naungan, gudang sarana, serta peralatan yang menunjang produksi (pengolah tanah, kultur jaringan, pengolah benih, panen, penyimpanan, transportasi, dan peralatan kantor). Pembiayaan operasional $\mathrm{BBH}$ berasal dari Anggaran Pendapatan dan Belanja Daerah (APBD), dengan kemungkinan dukungan Anggaran Pendapatan dan Belanja Negara (APBN), atau kerja sama dengan berbagai pihak sehingga lembaga mampu berkembang.

Menurut KBBI, istilah pembangunan berasal dari kata bangun yang berarti bentuk atau cara menyusun. Pembangunan dapat mempunyai arti yang beragam, jika dilihat dari sisi infrastruktur, pembangunan diartikan sebagai cara atau perbuatan membangun prasarana. Listiyaningsih dalam Karnita (2017) menyebutkan bahwa ciri kegiatan pembangunan adalah dilaksanakan secara sadar, bersifat komprehensif, terencana, bertahap dan berkesinambungan. Situs web pemerintah Kabupaten Buleleng menyebutkan bahwa pembangunan terbagi ke dalam 2 kategori, yaitu pembangunan fisik yang meliputi sarana dan prasarana, serta pembangunan nonfisik yang berkaitan dengan penggunaan sumber daya manusia.

Wijayanti (2019) mendefinisikan pariwisata edukasi sebagai perjalanan wisata yang menggabungkan unsur aktivitas wisata dan pendidikan, dimana muatan pendidikan disesuaikan dengan kurikulum yang bertujuan untuk memperkuat pembelajaran di ruang kelas. Wisata edukasi bertujuan untuk meningkatkan daya berpikir dan kreativitas wisatawan. Nilai tambah edukasi dapat memberi pengalaman baru bagi wisatawan yang menikmati perjalanan.

Direktorat Jendral Perlindungan Hutan dan Konservasi Alam (Ditjen PHKA) menyebutkan bahwa edutourism merupakan diversifikasi daya tarik dari ekowisata yang bertujuan memperluas dan memperbanyak produk wisata alam (Suryokusumo dkk., 2013). Pengembangan wisata pertanian ditujukan untuk memaksimalkan berbagai potensi di bidang terkait guna meningkatkan taraf hidup para pelaku, menjaga kelestarian lingkungan, pengembangan ilmu pengetahuan, serta meningkatkan kualitas dan produktivitas pertanian. Terdapat dua model pengembangan objek dan daya tarik agrowisata menurut Sastrayuda (2010), yaitu:

1. Pengembangan lanskap: meliputi pemanfaatan kawasan alam, budidaya pertanian, dan pengembangan wisata baru sesuai potensi yang ada.

2. Zonasi pengembangan wisata: bertujuan memberi kualitas pengalaman 
pengunjung dan memudahkan pengelola dalam beradaptasi, terdiri atas zona inti, zona penyangga, zona pelayanan, dan zona pengembangan.

Tujuan dari proyek pembangunan tersebut adalah untuk memperbaiki sistem pengorganisasian lembaga, memperbaiki standar layanan publik, dan melakukan penataan lebih lanjut. Sebagai lembaga yang berada di bawah Dinas Pertanian, segala aktivitas yang dilakukan BBH tidak bisa terlepas dari kebijakan pusat. Perizinan, penganggaran, alokasi sumber daya, dan pengawasan akan dilakukan pihak dinas terkait proses mewujudkan wisata edukasi pertanian.

Berbagai faktor dari luar dan dalam BBH dapat berdampak pada kegiatan operasional. Jumlah SDM yang minim, keterbatasan anggaran, sarana dan prasarana yang kurang memadai, serta waktu pelaksanaan yang singkat dapat menghambat keberlangsungan proyek. Berikut merupakan hal yang dapat mempengaruhi pembangunan (Lestari, 2015):

1. Perencanaan pembangunan yang merupakan tahapan awal dalam mencapai suatu tujuan, didalamnya memuat berbagai langkah-langkah yang perlu ditempuh.
2. Konsep pembangunan yang perlu disesuaikan dengan kondisi lembaga. Jika di dalamnya melibatkan pemerintah, perlunya memperhatikan peran, koordinasi, serta permasalahan timing dan political will, dimana pembangunan dilakukan sesuai kebutuhan masyarakat guna tercapainya kesejahteraan.

Sebagai instansi pemerintahan, aktivitas yang dilakukan BBH lebih berfokus pada pelayanan. Upaya pembangunan wisata edukasi pertanian dapat dijadikan media penyebarluasan informasi dan teknologi kepada masyarakat seputar perbenihan dan budidaya tanaman hortikultura. Terkait proyek yang sudah direncanakan, perlunya dilakukan peninjauan terhadap berbagai aspek untuk mengetahui kendala dan prospek pembangunan. Hal tersebut dilakukan untuk memastikan agar wisata edukasi pertanian dapat terwujud sesuai dengan tujuan yang direncanakan oleh lembaga. Penelitian ini bertujuan untuk mengidentifikasi berbagai faktor pendorong dan penghambat yang nantinya dapat digunakan sebagai masukan dalam perumusan strategi pembangunan wisata edukasi pertanian oleh $\mathrm{BBH}$ Kabupaten Garut. 


\section{METODE PENELITIAN}

Penelitian dilakukan menggunakan pendekatan kualitatif yang merupakan suatu kegiatan sistematis untuk melakukan eksplorasi teori dan fakta, dengan memanfaatkan fakta empiris sebagai sumber pengetahuan (Rukajat, 2012). Teknik yang digunakan dalam penelitian ini adalah studi kasus untuk mengungkapkan keunikan karakteristik yang terdapat dalam sebuah kasus yang diteliti (Stake dalam Fitrah dan Luthfiyah, 2017).

Data penelitian dianalisis dengan menggunakan SWOT dengan bantuan matriks IFAS dan EFAS untuk mengidentifikasi berbagai faktor strategis internal dan eksternal yang nantinya mempengaruhi pembangunan wisata edukasi pertanian di BBH Kabupaten Garut. Rangkuti (2017) menyebutkan bahwa SWOT didasarkan pada logika yang dapat memaksimalkan kekuatan (strength) dan peluang (opportunity), serta meminimalkan kelemahan (weakness) dan ancaman (threat).

\section{HASIL DAN PEMBAHASAN}

\section{Gambaran Umum}

Balai Benih Hortikultura merupakan Unit Pelaksana Teknis Daerah (UPTD) di bawah Dinas Pertanian Kabupaten Garut, berwenang dalam pengembangan pembibitan buah-buahan, sayuran, tanaman hias, dan biofarmaka. Lembaga tersebut didirikan pada tahun 1992 dengan nama BPMT (Blok Penggandaan Mata Tempel Jeruk) dengan produk yang dihasilkan yaitu mata entris jeruk untuk bahan pembibitan jeruk melalui okulasi. BBH dipimpin oleh seorang kepala unit setara Eselon IV/a dan membawahi beberapa subunit layanan teknis, seperti pemeliharaan pohon induk dan screen house, pemeliharaan kebun bibit dan kebun produksi, pemeliharaan tanaman hias, serta operasional dan pemeliharaan laboratorium.

Seiring dengan perkembangan zaman, pada tahun 2006 dan 2007 lembaga tersebut memiliki prioritas utama sebagai pelaksana program pengembangan benih jeruk, khususnya komoditas jeruk kepok garut. Keberlangsungan berbagai aktivitas ditunjang oleh penempatan aparat, sarana perkantoran, screen house, laboratorium, dan rumah jaga. Berdasarkan rencana strategis berjangka yang sudah ditetapkan (periode 2014-2019), kegiatan dan pelayanan yang diberikan dalam melaksanakan pengembangan pembenihan di Kabupaten Garut berfokus pada penyediaan mata entris jeruk yang berasal dari blok penggandaan mata tempel. Hal tersebut dapat dilakukan karena adanya dukungan dana dari Dana Alokasi Umum 
(DAU) Pemerintah Kabupaten Garut serta swadaya murni dari hasil budidaya di BBH. Selain itu, terdapat bantuan sarana, kerjasama dengan berbagai instansi, dan dukungan lainnya yang diperoleh melalui pemerintah maupun pelaku usaha.

Balai Benih Hortikultura Kabupaten Garut berlokasi di Jalan Raya Garut Cikajang km. 19, Desa Balewangi, Kecamatan Cisurupan, Kabupaten Garut, Jawa Barat. Lembaga tersebut memiliki lokasi yang strategis, meskipun saat ini untuk mengakses fasilitas lahan dan kantor perlu melewati bangunan milik Badan Penyuluh Pertanian (BPP) Kecamatan Cisurupan. BBH berada di ketinggian 1.200 mdpl dengan topografi $100 \%$ dataran tinggi, sehingga lahan cocok untuk ditanami berbagai sayur dan buah. Selain itu, curah hujan berkisar 1.500-2.200 $\mathrm{ml} /$ tahun dan suhu udara rata-rata berkisar $18-26^{\circ} \mathrm{C}$.

\section{Proyek Pembangunan Wisata Edukasi Pertanian BBH Kabupaten Garut}

Pembangunan wisata edukasi pertanian merupakan bagian dari optimalisasi peran dan fungsi lembaga untuk peningkatan pendapatan asli daerah (PAD) nonpajak. Proyek perubahan mengacu pada Keputusan Menteri Pertanian Nomor 347/Kpts/OT.210/6/2003 tentang pedoman pengelolaan balai benih tanaman pangan dan atau hortikultura serta Peraturan Daerah Pemerintah Kabupaten Garut Nomor 315 Tahun 2004 tentang Susunan Organisasi Tatakerja. Keberadaan proyek perubahan tersebut diharapkan terdapat pengelolaan dan penataan lahan $\mathrm{BBH}$ untuk penyediaan dan penyebarluasan benih/bibit serta melalui pelayanan wisata edukasi pertanian.

Proyek pembangunan bermanfaat sebagai wadah untuk terselenggaranya peran dan fungsi lembaga dengan visi dan misi guna kepentingan institusi dimana $\mathrm{BBH}$ dapat dijadikan sebagai tempat pendidikan pertanian. Inovasi yang dilakukan dapat membangun pertanian Kabupaten Garut melalui pelayanan edukasi yang diberikan. Pemilihan konsep wisata edukasi didasarkan pada kinerja lembaga yang berfokus pada pelayanan kepada masyarakat, sehingga tidak bisa sepenuhnya berorientasi kepada bisnis seperti agrowisata lainnya. Manfaat dari proyek tersebut adalah menjamin ketersediaan benih/bibit tanaman hortikultura sesuai kebutuhan masyarakat, membangun jiwa wirausaha bagi generasi muda, serta diharapkan terjadi peningkatan kondisi ekonomi masyarakat tani. 


\section{FAKTOR PENDORONG DAN PENGHAMBAT PEMBANGUNAN WISATA EDUKASI PERTANIAN \\ DI BALAI BENIH HORTIKULTURA KABUPATEN GARUT}

Syifa Al Mani, Lucyana Trimo

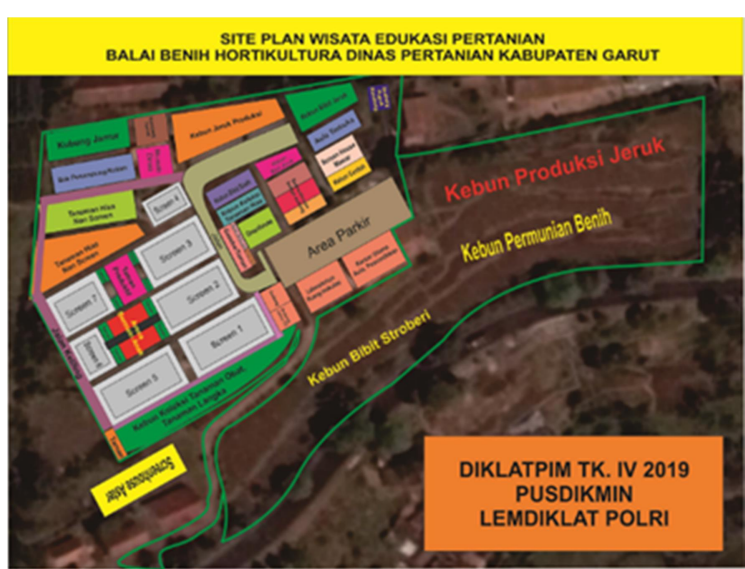

Gambar 2. Rancangan Tata Letak Wisata Edukasi Pertanian BBH Kabupaten Garut Sumber : BBH Kabupaten Garut

Perwujudan BBH sebagai destinasi wisata edukasi pertanian merupakan bagian dari proyek perubahan lembaga jangka panjang dengan durasi 1-2 tahun. Nantinya $\mathrm{BBH}$ akan terbagi ke dalam lima zona, yaitu:

\section{Zona Edukasi}

Merupakan areal yang menyediakan fasilitas learning by doing meliputi pendidikan dan pelatihan singkat seputar teknologi pembibitan dan budidaya tanaman jeruk, tanaman hias potong, sayuran, buah-buahan, dan biofarmaka.

\section{Zona Rekreasi}

Kawasan yang diberlakukan untuk umum dengan tiket masuk yang terjangkau. Fasilitas yang ada meliputi kebun koleksi tanaman hortikultura, kebun jeruk nusantara dan buah subtropika, kebun agro-inovasi, taman kreatif, kebun bunga, screen blok penggandaan mata tempel dan fondasi mata tempel jeruk, saung hidroponik, saung edukasi, saung paniisan, saung kreatif, saung lisung, teras $\mathrm{BBH}$, galadag selfie, coffee shop, dan sarana bermain anak.

3. Zona Pelayanan

Zona berikut bertujuan untuk meningkatkan kompetensi sumberdaya manusia guna menumbuhkan minat menjadi wirausaha tani melalui kegiatan magang, praktek kerja lapangan, penyuluhan, dan sebagainya. Materi pendidikan yang diberikan meliputi teknologi pembibitan, budidaya, panen, pascapanen, serta pemasaran hasil. Fasilitas penunjang zona pelayanan adalah pemondokan, ruang belajar, laboratorium kimia, laboratorium lapangan, serta ruang belajar terbuka.

4. Zona Agribisnis

Areal berikut hadir untuk memproduksi berbagai jenis bibit tanaman sebagai kebun koleksi, dijual, serta menerima pesanan dengan partai kecil sampai besar. Jenis tanaman yang diproduksi adalah tanaman hortikultura, blok penggandaan mata tempel jeruk, serta jamur tiram.

5. Zona Penyangga

Penataan lahan dengan memperhatikan konservasi dan estetika lingkungan, dimana lahan dengan kemiringan $30^{\circ}$ nantinya akan dilengkapi dengan taman dengan pemandangan 
Gunung Cikuray, hamparan sawah, merupakan kondisi internal lembaga yang perkotaan, dan kebun sayuran. Kawasan menghambat tercapainya suatu tujuan. tersebut menyediakan fasilitas kebun jeruk nusantara dan buah subtropika, jogging track, galadag selfie, tower view, kebun buah petik sendiri, saung paniisan, camping ground, dan agro inovasi.

Selain pembangunan, BBH akan menambah komponen dalam struktur organisasinya seperti adanya petugas administrasi dan keuangan, pemandu wisata, petugas keamanan, dan subunit pelayanan laboratorium. Penambahan bagian administrasi dan keuangan bertujuan agar urusan ketatausahaan, inventaris, dan pengelolaan keuangan lembaga menjadi lebih tertata. Keberadaan pemandu wisata dan petugas keamanan mempengaruhi kenyamanan dan keamanan dari perjalanan wisata edukasi yang akan dilakukan. Selain itu, subunit pengelolaan dan pelayanan laboratorium bertujuan untuk memaksimalkan kinerja laboratorium sebagai tempat penelitian.

\section{Analisis Faktor Pendorong dan Pembangunan Wisata Edukasi BBH Kabupaten Garut}

1. Faktor internal

Faktor internal terdiri atas kekuatan (strength) yang merupakan keadaan internal yang membantu lembaga dalam mencapai tujuan, serta kelemahan (weakness) yang

Tabel 2. Matriks IFAS Pembangunan Wisata Edukasi Pertanian di BBH Kabupaten Garut

\begin{tabular}{|c|c|c|c|}
\hline $\begin{array}{c}\text { Faktor-Faktor } \\
\text { Strategi Internal }\end{array}$ & Bobot & Rating & Skor \\
\hline \multicolumn{4}{|l|}{ KEKUATAN } \\
\hline $\begin{array}{l}\text { a. Kondisi alam yang } \\
\text { mendukung } \\
\text { proyek } \\
\text { pembangunan. }\end{array}$ & 0,083 & 4 & 0,333 \\
\hline $\begin{array}{l}\text { b. Lokasi BBH yang } \\
\text { strategis. }\end{array}$ & 0,075 & 3,5 & 0,263 \\
\hline $\begin{array}{l}\text { c. Luas lahan utama } \\
\text { dan lahan } \\
\text { tambahan yang } \\
\text { memadai. }\end{array}$ & 0,069 & 3,2 & 0,222 \\
\hline $\begin{array}{l}\text { d. Beberapa fasilitas } \\
\text { penunjang } \\
\text { kegiatan di BBH } \\
\text { sudah ada dan } \\
\text { berfungsi. }\end{array}$ & 0,069 & 3,5 & 0,243 \\
\hline $\begin{array}{l}\text { e. SDM yang } \\
\text { berpengalaman di } \\
\text { bidang budidaya } \\
\text { tanaman } \\
\text { hortikultura. }\end{array}$ & 0,056 & 3 & 0,167 \\
\hline $\begin{array}{l}\text { f. Komitmen dari } \\
\text { internal lembaga } \\
\text { dan pemangku } \\
\text { kebijakan lainnya. }\end{array}$ & 0,042 & 2,7 & 0,113 \\
\hline $\begin{array}{l}\text { g. Orientasi proyek } \\
\text { pada aspek } \\
\text { pendidikan, bukan } \\
\text { bisnis semata. }\end{array}$ & 0,083 & 3,7 & 0,308 \\
\hline $\begin{array}{l}\text { h. Proses } \\
\text { pembangunan } \\
\text { dilakukan secara } \\
\text { bertahap. }\end{array}$ & 0,056 & 2,5 & 0,139 \\
\hline TOTAL SKOR & & & 1,788 \\
\hline KELEMAHAN & & & \\
\hline $\begin{array}{l}\text { a. Kurangnya sarana } \\
\text { dan prasarana } \\
\text { penunjang } \\
\text { pembangunan } \\
\text { wisata edukasi } \\
\text { pertanian. }\end{array}$ & 0,083 & 1,5 & 0,125 \\
\hline $\begin{array}{l}\text { b. Terbentur dengan } \\
\text { peraturan daerah. }\end{array}$ & 0,042 & 1,7 & 0,071 \\
\hline $\begin{array}{l}\text { c. Kurangnya } \\
\text { anggaran. }\end{array}$ & 0,083 & 1 & 0,083 \\
\hline $\begin{array}{l}\text { d. Jangka waktu } \\
\text { proyek hanya } \\
\text { berkisar } 1-2 \text { tahun. }\end{array}$ & 0,056 & 1,5 & 0,083 \\
\hline
\end{tabular}




\section{FAKTOR PENDORONG DAN PENGHAMBAT PEMBANGUNAN WISATA EDUKASI PERTANIAN \\ DI BALAI BENIH HORTIKULTURA KABUPATEN GARUT \\ Syifa Al Mani, Lucyana Trimo}

\begin{tabular}{|c|c|c|c|}
\hline \multicolumn{4}{|l|}{ KELEMAHAN } \\
\hline $\begin{array}{l}\text { e. Jumlah dan } \\
\text { kompetensi SDM } \\
\text { yang kurang untuk } \\
\text { menunjang } \\
\text { keberlangsungan } \\
\text { proyek. }\end{array}$ & 0,083 & 1,3 & 0,108 \\
\hline $\begin{array}{l}\text { f. Masih bergantung } \\
\text { pada pemerintah } \\
\text { dalam memenuhi } \\
\text { berbagai } \\
\text { kebutuhan } \\
\text { lembaga. }\end{array}$ & 0,064 & 2 & 0,128 \\
\hline $\begin{array}{l}\text { g. Terhambatnya } \\
\text { keberlanjutan } \\
\text { proyek jika adanya } \\
\text { pergantian } \\
\text { pimpinan. }\end{array}$ & 0,056 & 1,7 & 0,094 \\
\hline TOTAL SKOR & & & 0,693 \\
\hline
\end{tabular}

TOTAL

ah (2020)

Berdasarkan Tabel 2, terdapat 15 faktor internal yang terdiri atas 8 kekuatan dan 7 kelemahan. Faktor yang dianggap paling menunjang pembangunan wisata edukasi pertanian adalah kondisi alam yang sesuai dengan aktivitas pertanian di $\mathrm{BBH}$ (skor: 0,333), dimana BBH berada di daerah dataran tinggi dan komoditas pertanian yang tersedia adalah berbagai tanaman hortikultura seperti jeruk, tomat, berbagai sayuran dan bunga hias potong. Hal tersebut didukung oleh lokasi yang strategis, luas lahan yang memadai, keberadaan fasilitas yang sudah berfungsi, serta SDM yang ahli di bidang budidaya. Destinasi wisata pertanian harus memiliki tempat yang strategis dan mudah dijangkau (Usman, 2012). Lembaga berfokus untuk mewujudkan destinasi wisata yang berfokus pada aspek pendidikan, konsep tersebut menjadi daya tarik. Proses pembangunan dilakukan secara berkala melalui penataan.

Faktor internal yang menghambat pembangunan adalah terbenturnya rencana dengan tugas pokok dan fungsi lembaga (skor: 0,071), BBH merupakan UPTD sehingga semua aktivitas mulai dari perencanaan, perizinan, pelaksanaan, hingga evaluasi akan bergantung pada kebijakan Dinas Pertanian. Kondisi tersebut akan mempengaruhi aspek lainnya seperti jumlah anggaran dan bantuan saran prasarana yang diterima serta penempatan SDM. Keterbatasan waktu proyek dapat mempersulit perwujudan wisata edukasi yang ideal sesuai dengan tujuan. Selain itu, pergantian pimpinan balai dapat mempengaruhi keberlanjutan proyek karena adanya perbedaan visi dan misi yang dibawakan.

\section{Faktor eksternal}

Faktor eksternal yang diperoleh dan akan dianalisis adalah peluang (opportunity) yang merupakan kondisi eksternal yang menunjang lembaga dalam mencapai tujuan tertentu serta ancaman (threat) yang merupakan faktor dari luar lembaga yang menghambat tercapainya suatu tujuan. 
Tabel 3. Matriks EFAS Pembangunan Wisata Edukasi Pertanian di BBH Kabupaten Garut

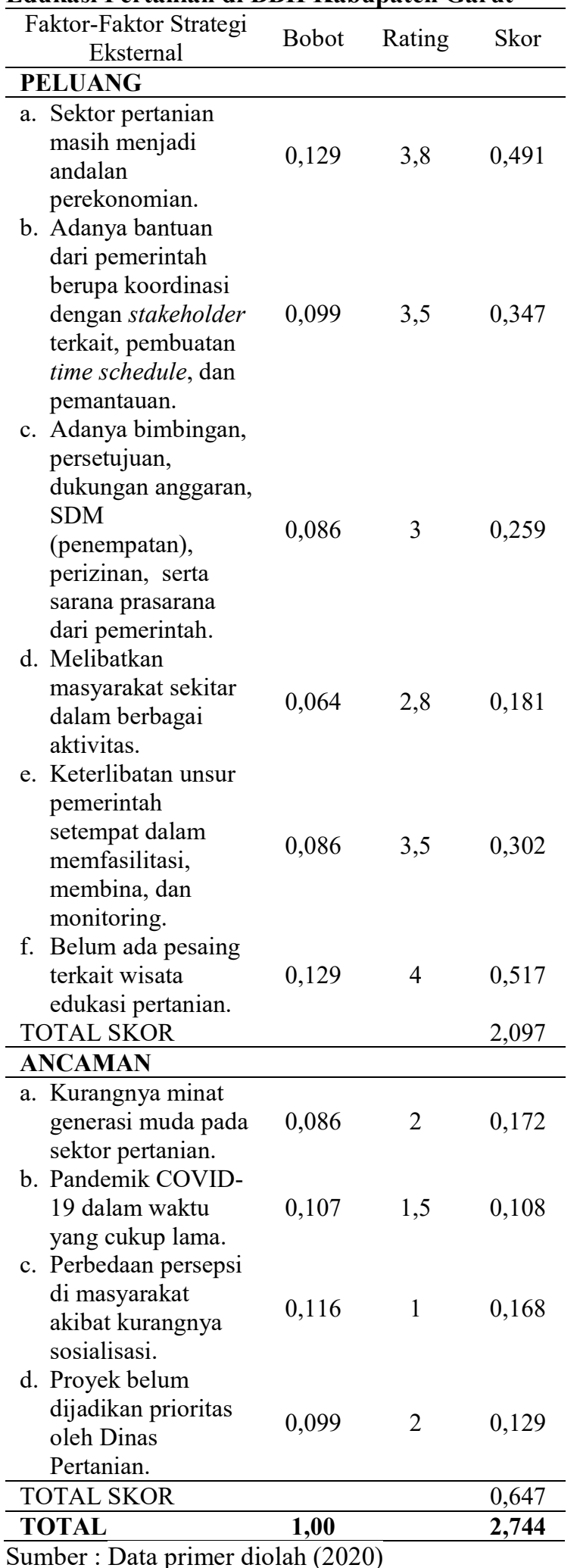

Berdasarkan Tabel 3, dapat diketahui bahwa terdapat 10 faktor eksternal terdiri atas 6 peluang dan 4 ancaman yang dianggap mampu mempengaruhi pembangunan wisata edukasi pertanian di $\mathrm{BBH}$ Kabupaten Garut. Belum adanya pesaing merupakan peluang yang mempunyai pengaruh besar terhadap proses pembangunan (skor: 0,517), hal tersebut menjadikan $\mathrm{BBH}$ sebagai satu-satunya destinasi wisata edukasi pertanian di Kabupaten Garut khususnya Kecamatan Cisurupan. Aktivitas ekonomi masyarakat yang bergantung pada sektor pertanian dapat menunjang keberlangsungan operasional dan pembangunan. Selain itu, keterlibatan Dinas Pertanian, pemerintah setempat, dan masyarakat dapat membantu dalam perwujudan wisata edukasi pertanian melalui bantuan, bimbingan, dan kerja sama. Komitmen dan partisipasi stakeholders dalam menjalani tupoksi dan peran masing-masing dipengaruhi oleh kualitas dan kuantitas koordinasi (Mahfud dkk., 2015).

Faktor ancaman yang paling berpengaruh pembangunan adalah adanya pandemi COVID-19 dalam waktu yang cukup lama (skor: 0,108), kondisi tersebut menjadikan Pemerintah Kabupaten Garut memprioritaskan penanganan masalah kesehatan sehingga sehingga berdampak pada pengalokasian anggaran. Hal tersebut berkaitan dengan proyek yang belum 
dijadikan prioritas atau belum dimuat dalam rencana strategis atau rencana kerja oleh Dinas Pertanian selaku pemegang kebijakan. Penghambat lain dalam keberlangsungan proyek ini adalah kurangnya sosialisasi yang dilakukan oleh $\mathrm{BBH}$ sehingga menimbulkan perbedaan persepsi di masyarakat, serta kurangnya minat generasi muda terhadap sektor pertanian.

\section{Faktor Pendorong dan Penghambat}

Berdasarkan matriks IFAS dan EFAS, kekuatan dan peluang merupakan faktor pendukung, serta kelemahan dan ancaman dapat menjadi faktor penghambat dalam pelaksanaan pembangunan wisata edukasi (Maulana, 2011). Faktor pendorong merupakan hal-hal yang mendukung keberhasilan suatu kegiatan (Lestari, 2018). Jika merujuk pada KBBI, faktor penghambat berarti keadaan atau penyebab yang menghalangi pencapaian suatu hal.

Hasil perolehan dan analisis data menunjukkan bahwa faktor pendorong dalam menjalankan proyek tersebut adalah sebagai berikut:

1) Kondisi alam dan lahan yang memadai serta keberadaan beberapa fasilitas yang sudah berfungsi.

Modal dan potensi alam merupakan atraksi yang mendorong seseorang melakukan perjalanan wisata (Mellu dan Bessie, 2018). Luas lahan yang memadai, ketersediaan sumber daya air, dan kondisi cuaca yang mendukung kegiatan budidaya tanaman hortikultura merupakan salah satu modal $\mathrm{BBH}$ dalam menjalankan aktivitas. Memanfaatkan sumber daya yang tersedia dapat menunjang penataan dan pembangunan.

2) SDM yang ahli di bidang budidaya.

Keberadaan tenaga kerja yang ahli dan berpengalaman di bidang budidaya dapat membantu kegiatan produksi di $\mathrm{BBH}$. Salah satu aspek yang mempengaruhi dalam perencanaan pembangunan adalah kinerja sumber daya aparatur (Setianingsih dkk., 2015).

3) Proyek yang berorientasi pada aspek pendidikan.

BBH mencanangkan wisata edukasi pertanian sebagai media pembelajaran dengan melihat objek langsung di lapangan yang bermanfaat untuk menambah pengetahuan dan meningkatkan kesadaran memelihara lingkungan (Hanapi dkk., 2017). Nantinya BBH akan menyediakan fasilitas belajar langsung di lapangan terkait pengenalan dan pembibitan berbagai tanaman hortikultura.

4) Belum adanya pesaing wisata edukasi.

Terdapat beberapa destinasi wisata pertanian di Kabupaten Garut seperti wisata 
petik jeruk Eptilu di Kecamatan Cikajang, agrowisata taman hias di Kecamatan Ciledug, dan buah naga di Kecamatan Bayongbong. Perbedaan konsep dengan $\mathrm{BBH}$ tidak menjadikan keberadaan agrowisata tersebut sebagai pesaing, karena wisata edukasi yang dicanangkan memiliki daya tarik yang berasal dari pelayanan pendidikan dan keindahan alam yang disuguhkan.

5) Komitmen internal lembaga dan dukungan dari berbagai stakeholders.

Aspek kelembagaan merupakan hal yang memiliki pengaruh terhadap pembangunan wisata, dimana hal tersebut dapat meliputi pemanfaatan dan peningkatan kapasitas institusi yang berdampak pada operasional (Mellu dan Bessie, 2018). Menurut Peraturan Bupati Garut Nomor 68 tahun 2016 tentang Tugas, Fungsi dan Tata Kerja Dinas Pertanian Kabupaten Garut, pihak dinas akan memberi bantuan berupa pembuatan time schedule, koordinasi dengan stakeholder terkait, serta melakukan pemantauan.

6) Sektor pertanian yang masih menjadi andalan perekonomian daerah.

Pertanian, kehutanan, dan perikanan mendominasi Produk Domestik Regional Bruto (PDRB) atas harga berlaku Kabupaten Garut pada tahun 2015-2019 (BPS, 2020). Cisurupan sebagai salah satu daerah agropolitan merupakan peluang untuk membangun sektor pertanian guna peningkatan kesejahteraan. Hal tersebut dapat ditunjang melalui keterlibatan masyarakat dapat mengatasi permasalahan tenaga kerja, membantu pembangunan, dan mengembangkan potensi daerah (Melati dan Narottama, 2020).

Faktor penghambat yang dihadapi BBH dalam mewujudkan wisata edukasi pertanian adalah:

1) Terbenturnya perencanaan dengan peraturan daerah.

Rencana pembangunan wisata edukasi pertanian dapat dikatakan kurang sesuai dengan tugas pokok dan fungsi dari $\mathrm{BBH}$ dan visi misi lembaga yang berfokus pada penyebarluasan dan pelayanan pembibitan jeruk keprok garut. Dengan adanya proyek wisata edukasi, BBH perlu menyiapkan sumber daya tambahan untuk menunjang setiap aktivitas di dalamnya. Permasalahan kesesuaian tupoksi dapat berpengaruh pada kebijakan perizinan dan penganggaran yang nantinya diputuskan oleh Dinas Pertanian.

2) Keterbatasan berbagai sumber daya (SDM, waktu, anggaran, sarana dan prasarana).

Keterbatasan dana akan mempengaruhi kegiatan operasional dan proses pembangunan (Setianingsih, 2015). 
Selain dana, BBH memerlukan SDM dengan jumlah dan kompetensi yang sesuai untuk menunjang aktivitas wisata edukasi pertanian nantinya. Pengadaan sarana dan prasarana dapat dipertimbangkan sesuai dengan konsep agar pembangunan berjalan efektif dan efisien.

3) Kebergantungan pada pemerintah dalam pemenuhan berbagai kebutuhan.

Keberlangsungan aktivitas di $\mathrm{BBH}$ sangat bergantung pada perizinan Dinas Pertanian Kabupaten Garut dan dana yang turun dari pemerintah pusat. Pemerintah mempunyai peran penting sebagai pengambil keputusan tertinggi (Ismayanti dkk., 2014).

4) Terhambatnya keberlanjutan proyek jika ada pergantian pimpinan.

Pergantian pimpinan dan kebijakan dapat mempengaruhi keberlangsungan program. Hal tersebut dapat diantisipasi dengan pembuatan cetak biru bertujuan memberi arahan dalam suatu kegiatan sehingga sesuai dengan tuntutan, tantangan, dan kebutuhan lingkungan sekitar (Zulkarnain dkk., 2018), dengan harapan wisata edukasi dapat terwujud sesuai dengan tujuan awal dan bermanfaat bagi internal dan eksternal BBH.

5) Kurangnya sosialisasi masyarakat.
$\mathrm{BBH}$ perlu melakukan sosialisasi untuk meningkatkan keterlibatan masyarakat yang dapat mempengaruhi operasional (Itamar dkk., 2014). Sosialisasi dilakukan untuk menghindari perbedaan persepsi terkait $\mathrm{BBH}$ serta dapat menjadi gerbang awal dalam bermitra.

6) Adanya pandemi COVID-19.

Pandemi COVID-19 berpengaruh pada alokasi dana dimana pemerintah akan memprioritaskan untuk penyelesaian masalah kesehatan. Hal tersebut berpengaruh pada anggaran yang seharusnya diterima dan digunakan $\mathrm{BBH}$, yang secara tidak langsung dapat menghambat realisasi wisata edukasi pertanian.

\section{KESIMPULAN DAN SARAN}

\section{Kesimpulan}

BBH sebagai UPTD di bawah Dinas Pertanian Kabupaten Garut mengadakan upaya optimalisasi fungsi dan peran lembaga melalui pembangunan wisata edukasi pertanian. Lembaga tersebut nantinya akan memberikan pelayanan pendidikan pertanian khususnya seputar tanaman hortikultura, dimana didalamnya terdapat berbagai zona dan fasilitas yang menunjang. Dalam merealisasikan wisata edukasi, BBH dipengaruhi oleh berbagai 
faktor yang berasal dari dalam dalam lembaga.

Faktor pendorong pembangunan wisata edukasi di BBH Kabupaten Garut adalah sebagai berikut:

- BBH memiliki kondisi alam dan lahan yang memadai serta keberadaan beberapa sarana dan prasarana yang berfungsi.

- Keberadaan SDM yang ahli dan berpengalaman di bidang budidaya.

- Proyek pembangunan yang berorientasi pada aspek pendidikan.

- Belum adanya pesaing terkait wisata edukasi pertanian.

- Adanya komitmen dari internal lembaga dan dukungan dari berbagai stakeholders.

- Sektor pertanian yang masih menjadi andalan perekonomian daerah.

Faktor penghambat pembangunan wisata edukasi di BBH Kabupaten Garut adalah sebagai berikut:

- Kurang sesuainya perencanaan dengan peraturan daerah (tupoksi).

- Keterbatasan sumber daya.

- Kebergantungan yang tinggi pada pemerintah dalam menjalankan berbagai kegiatan.

- Keberlanjutan proyek akan terhambat jika terjadi pergantian pimpinan.
BBH kurang melakukan sosialisasi kepada masyarakat.

Adanya pandemi COVID-19 yang berpengaruh pada alokasi dana dari pemerintah pusat.

\section{Saran}

1. Memaksimalkan aktivitas pertanian dan pembangunan/penataan yang sudah berjalan dengan tetap meminta pemantauan dari Dinas Pertanian.

2. Melakukan pengelolaan sosial media untuk memperluas jaringan pemasaran dimana pendapatan yang diperoleh bisa dialokasikan untuk pembangunan.

3. Melakukan pengajuan kepada Dinas Pertanian dalam pemenuhan sumber daya yang menunjang realisasi wisata edukasi pertanian.

4. Meningkatkan koordinasi dan kerja sama dengan berbagai stakeholders untuk sosialisasi dan promosi.

5. Melakukan evaluasi terkait kemajuan proyek agar kedepannya pembangunan dapat berjalan dengan efektif dan efisien.

\section{DAFTAR PUSTAKA}

Databoks. (2018, 10 September) . Berapa Pendapatan Devisa dari Sektor Pariwisata Indonesia?. Diakses pada 1 September 2020, dari databoks.katadata.co.id/datapublish/2 


\section{FAKTOR PENDORONG DAN PENGHAMBAT PEMBANGUNAN WISATA EDUKASI PERTANIAN DI BALAI BENIH HORTIKULTURA KABUPATEN GARUT \\ Syifa Al Mani, Lucyana Trimo}

018/09/10/berapa-pendapatan-devisadari-sektor-pariwisata-indonesia

Fitrah, Muh. dan Luthfiyah. 2017. Metodologi Penelitian ; Penelitian Kualitatif, Tindakan Kelas \& Studi Kasus. CV. Jejak, Kab. Sukabumi.

Hanapi, Emirta dkk. 2017. Pemanfaatan Objek Wisata Sebagai Sumber Pembelajaran Kontekstual. Pascasarjana Dikdas IPS UNM.

Itamar, Hugo dkk. 2014. Strategi Pengembangan Pariwisata di Kabupaten Tana Toraja. Government : Jurnal Ilmu Pemerintahan. 7(2) : 91-108.

Lestari, Asih Widi. (2018). Faktor Pendukung dan Faktor Penghambat dalam Mewujudkan Pembangunan Pariwisata Berwawasan Lingkungan di Kota Batu. Prosiding Senas POLIH ke-1 Tahun 2018. Fakultas Ilmu Sosial Ilmu Politik Universitas Wahid Hasyim. Semarang. pp. 29-36.

Lestari, Iles Sinta. 2015. Faktor-Faktor yang Mempengaruhi Pembangunan Infrastruktur (Jalan dan Jembatan) di Kecamatan Kampar Kiri Hulu Kabupaten Kampar Tahun 20112013. Jom FISIP. 3(1) : 1-13.

Maulana, Heri dkk. 2012. Strategi Pengembangan Pariwisata di Kabupaten Pati. Public Policy and Management Review. 1(1) : 1-37.

Melati, Bella Vhintya dan Nararya Narottama. 2020. Keterlibatan Masyarakat Dalam Pengelolaan Agrowisata di Desa Tulungrejo, Kota Batu (Studi Kasus : Top Apel Mandiri). Destinasi Pariwisata. 8(1) : 82-91.

Mellu, Marlin Rosianti dan Tobias Tokan Bunga. 2018. Analisis Faktor Penunjang dan Penghambat Pengembangan Objek Wisata (Studi Pada Objek Wisata Alam Bola Palelo, Kecamatan Mollo Tengah, Kabupaten Timor Tengah Selatan). Journal of Management (SME's). 7(2) : 269-286.
Muchlis, Suryadi dan Eko Budi Santoso. 2017. Penentuan Kriteria Pengembangan Agrowisata di Kecamatan Sukapura Kabupaten Probolinggo. Teknik ITS. 6(2): 233373520 .

Rangkuti, Freddy. 2017. Analisis SWOT: Teknik Membedah Kasus Bisnis. PT. Gramedia Pustaka Utama, Jakarta.

Republik Indonesia. 2003. Keputusan Menteri Pertanian NOMOR : 347/Kpts/OT.210/6/2003 tentang Pedoman Pengelolaan Balai Benih Tanaman Pangan dan Hortikultura. Sekretariat Negara. Jakarta.

Rukajat, Ajat. 2012. Pendekatan Penelitian Kualitatif (Qualitative Research Approach). Deepublish, Yogyakarta.

Sastrayuda, Gumelar S. 2010. Hand Out Mata Kuliah Concept Resort and Leisure, Strategi Pengembangan dan Pengelolaan Resort and Leasure. Universitas Pendidikan Indonesia.

Setianingsih, Budhi dkk. 2015. Efektivitas Sistem Perencanaan Pembangunan Daerah (Simrenda). Administrasi Publik (JAP). 3(11) : 1930-1936.

Suryokusumo, Beta dkk. 2013. Perancangan Wisata Edukasi Lingkungan Hidup di Batu dengan Material Alami. Arsitektur Universitas Brawijaya. 1(1) : 1-12.

Usman dkk. 2012. Strategi Pemerintah Daerah Dalam Pengembangan Agrowisata di Kabupaten Banteng. Otoritas : Jurnal Ilmu Pemerintahan. 2(2) : 191-200.

Wijayanti, Ani. 2019. Strategi Pengembangan Pariwisata Edukasi di Kota Yogyakarta. Deepublish, Yogyakarta.

Zulkarnain dkk. 2018. Identifikasi dan Penyusunan Cetak Biru Program Laboratorium Site. ABDIMAS PEDAGOGI: Jurnal Ilmiah Pengabdian kepada Masyarakat. 1(2): 178-187. 